\title{
Editorial: The Role of the African Intellectual Diaspora in Advancing Higher Education
}

\author{
Damtew Teferra
}

Writing on the topic of this issue in 2004, I observed that the effort to return African immigrant intellectuals to their homelands has been an uphill struggle-and also a disappointment. As a consequence, a new discourse and approach to mobilise intellectual diaspora communities to enhance the continent's social, economic, and intellectual progress without necessarily relocating them physically is gathering momentum (Teferra, 2004). Fast forward, in 202I, as we read in this special issue, that momentum has gathered more steam with intensified efforts to deploy the intellectual diaspora in higher education.

The potential of scholastic benefits from the diaspora community can be gauged by the staggering statistics on the size and quality of this community abroad, many of whose members pursue academic and scholarly professions as university professors, researchers, engineers, medical doctors, and high-level technicians. For instance, in the US alone, one in two African diaspora has a university degree. The need to mobilise this potentially powerful force goes beyond the oft-cited economic benefits as it plays a considerable role in stimulating and catalysing home-based academic and scholarly institutions (Teferra, 2003, 2018).

The diaspora is widely acknowledged as a critical resource for the development and revitalisation of higher education in Africa. However, tapping that resource, and forging mutually beneficial academic relationships with diasporans and Africa-based scholars and institutions, remains tricky (Dell, 2020) and fraught with challenges (Teferra, 2003).

The dominant discourse around the African academic diaspora follows a distinct pattern of deficit: the wide-ranging costs of losing some of the continent's best and brightest intellectuals. However, this clouds the expansive and often innovative relationships that African academic diasporans have forged with scholars and institutions across the continent-relationships that build and reinforce both scholarly and personal engagements (Foulds and Zeleza, 20I4). 
According to the Societe Francaise de Realisation D'etudes et de Conseil (SOFRECO) (2007), issues of migration and development have been at the centre of various joint African-European initiatives. Yet, the role of academic migrants and diasporas has not been addressed in a systematic way, despite a couple of important interventions and academic contributions. Given the increasing importance of internationalisation of higher education and research cooperation in the world, there has been growing interest in the role of diaspora not only with regard to Africa but also for other regions. As a consequence, many international development partners are planning to draw on the assistance of the African diaspora in higher education. For instance, the Africa-EU Summit held in Lisbon in December 2007 adopted the Joint Africa-EU Strategic Partnership, with one of its priorities being to build the capacity of higher education in Africa by facilitating mutually beneficial cooperation in higher education systems between Europe and Africa.

In the United States (US), the Carnegie African Diaspora Fellowship Program responds to this new approach by tapping the African intellectual diaspora through a fellowship programme for educational projects at African higher education institutions. Its five-year impact report indicates that faculty exchanges between diaspora academics in the US and Canada, and African higher education institutions lead to sustained linkages and research development in the form of grant collaboration, teaching and mentoring, improved programme offerings in African institutions, and community impacts (Carnegie, 20I9).

The African Union (AU), which recognises the African diaspora as the 6th region of the continent, defines it as "Consisting of people of African origin living outside the continent, irrespective of their citizenship and nationality and who are willing to contribute to the development of the continent and the building of the African Union." Its constitutive act declares that it shall "invite and encourage the full participation of the African Diaspora as an important part of our continent, in the building of the African Union." (AU). This definition and provision clearly indicate the Union's strong intent to involve and engage the diaspora in the continent's development agenda.

\section{The Diaspora Conference}

This special issue is an outcome of a major conference, "Continental Forum on the Role of the Diaspora in Higher Education, Research, and Innovation in Africa" organised in November 20I9 by the Institute of African Studies, Carleton University, Canada with the Citizens and Diaspora Directorate (CIDO) of the AU through funding from the Carnegie Corporation of New York at the Union's headquarters in Addis Ababa, Ethiopia. The overall intent and anticipated outcome of this event was well captured by the AU Commission in the context of its strategic objectives (AUC, 20I9).

The Forum attracted participants from a range of relevant stakeholders including the AU Commission, AU member states' focal agencies for the diaspora and education, government ministries and officials, African diaspora programme administrators, educational leaders, including professional associations and think tanks such as the Association of African Universities (AAU), the Council for the Development of Social Science Research in Africa (CODESRIA), and the Pan-African Doctoral Academy (PADA). It drew more than 80 participants from numerous countries including Algeria, Botswana, Cameroon, Central African Republic, Eritrea, Ethiopia, Gambia, Ghana, Kenya, Liberia, Malawi, Morocco, Mozambique, Nigeria, Rwanda, Senegal, South Africa, Uganda and Zambia, as well as Australia, Canada, China, Germany, India, the United Kingdom and the US.

The Forum explored the perspectives of government ministers and vice-chancellors on the role of the academic diaspora in African higher education. Officials provided their views on the potential of the academic diaspora to contribute to teaching and research across disciplines in higher education institutions. University leaders discussed what can and cannot be achieved through engagements with diaspora academics and what they see as the drivers of, and constraints to, success.

The session also discussed government-led academic diaspora engagement programmes and explored outcomes and effective practices. Panellists drawn from the University of Ottawa, Canada, Peking University, China, and the National Institute of Education Planning and Administration, India presented comparative contexts and incentives of government-led academic diaspora initiatives in Europe, Asia, and Latin America; experiences and results of government programmes in China; and outcomes of a decade of academic diaspora initiatives in India, respectively.

In the session on regional policy and practice of academic diaspora engagement, a number of Africa-based panellists discussed either existing policies or those that are required, to ensure that diaspora engagement programmes achieve their objectives. Other panellists discussed the rationale for and distinguishing features of various programme approaches to diaspora engagement and what they have and have not achieved.

The panel also highlighted the status of the implementation of the Continental Education Strategy for Africa (CESA), one of the derivatives of the AU's Agenda 2063, in terms of activities and programmes planned or completed thus far, and discussed the development of concrete and actionable measures by which the various stakeholders would contribute, in the short to medium term, with particular emphasis on higher education 
through partnership and synergies between diaspora partners and Africabased counterparts.

The Forum further discussed harmonising existing and new interventions with CESA. The purpose was to align the numerous diaspora-led interventions in higher education within the framework and objectives of the CESA Higher Education cluster and to formulate a set of recommendations for the AU on how to integrate regional and global best practices within the ongoing execution of the CESA.

In exploring intercultural competencies in diaspora engagement, different mechanisms to address the working relationship between academic diaspora and host institutions in politically and culturally sensitive environments were a particular focus. The purpose was to contribute to the development of an operational toolkit for academic partnerships between diaspora higher educators and host institutions on the continent.

The conference also discussed government-led academic diaspora engagement programmes, their outcomes and effective practices. It heard testimonials and experiences of diaspora initiatives and came up with recommendations from diaspora academics and hosting academics on a way forward for policy frameworks to enable effective action at the regional, national, and institutional levels.

In advancing and enhancing national policy frameworks, mechanisms for integrating academic diaspora programmes within member states' existing diaspora engagement policies were discussed. The outcomes were intended to contribute to the development of a roadmap to support member states to translate policy into implementation.

The Forum was enriched by a number of commissioned papers presented at the event, two of which by Gueye and Boatemaa and colleagues are part of this special issue. Two articles are contributed by Forum participantsVarghese and Woldegiyorgis - who benefitted from the dialogue. A further two-by Oanda and Obonyo, and Wapmuk- were solicited to broaden the context and perspectives for a viable special issue.

\section{Articles in this Special Issue}

A total of six articles on intellectual diaspora are included in this issue covering Africa, and also specific countries including Ethiopia, Ghana and Nigeria. A comparative perspective from India, that has one of the largest intellectual diasporas in the world, is also included.

Based on data from IO2 Africa-based academics, Gueye explored the level and forms of their relationships with diaspora academics to establish the scale of the diaspora's intervention in higher education in Africa. He focused on actors based in Africa who could testify on the diaspora's intervention on the continent; in so doing, he targeted others reporting what the diaspora claims for themselves. He organised his observations into nine different roles, including co-authorship of articles and research proposals; co-hosting of conventions; peer reviewing; academic visitation; co-teaching and co-supervision of students; among others. Gueye argues that while diaspora scholars are urged to contribute in Africa, they also have to contend with the challenges and expectations in their host institutions and the global academic discourse in general. In addition to the plethora of such expectations, he observes that the diaspora is expected to meet all these requirements in a particular historical context constrained by the dearth of time-which he describes as a core resource for all academics seeking to make a difference in their profession-with implications for the nature and scope of their contributions and engagement.

Setrana, Arhin-Sam, Mensah, and Kyei used Ghana as a case study to explore the extent of the nation's interest and readiness to engage its academic diaspora through the setting up of programmes, institutions and policy guidelines for the development of the higher education sector in the country. They conceptualise academic diaspora policy engagement as capacity building and extending rights and privileges to academic diaspora for the purposes of establishing the appropriate atmosphere for skills to be transferred to the home country for development. Using Gamlen's typologies on the policy approaches employed by countries to engage their diaspora, they extend the argument that for the extraction of obligation to function optimally, the institutions, programmes and policies should be workable and flexible to accommodate transfer of skills into Ghana's high education sector. Recounting a number of diaspora activities under the wider umbrella of institution building, they note the creation of consular and consultative bodies; transnational networks and ministerial agencies to manage diaspora engagements including academic diaspora. The authors conclude that capacity building efforts and extending rights and privileges to the diaspora are important elements that need to be instituted by the government of Ghana to motivate the extraction or contribution of the skills of experienced and highly skilled academics.

Based on in-depth interviews with I6 Ethiopian diaspora academics based in the US, Woldegiyorgis interrogated the professional, personal, familial and other individual attributes that are known to shape the trajectories of diaspora engagements. This study, which was informed by a phenomenological research design, explored how Ethiopian academic diaspora in the US engage with universities in Ethiopia, and more specifically how this engagement is framed by factors in their personal spaces, from their own conception of the process and experiences. While acknowledging the importance of examining broader institutional, policy and other environmental forces' effect on diaspora engagement, this article advances 
that the backgrounds, experiences and personal attributes of the individual diaspora academic are worthy of equal consideration as they determine decisions to get engaged, and shape the interaction with various aspects of the broader environment. Woldegiyorgis advocates for a holistic approach to studying diaspora engagement in higher education that pays as much attention to the personal and microenvironmental as it does to the institutional, legal and political.

Writing on the Indian diaspora, Varghese points out that, the country accounted for the largest share of global migration in 2019, with more than I7.5 million of 272 million. He observes that expansion of the diaspora takes place through migration of highly educated migrants seeking employment and through cross-border student mobility in search of higher education. He stresses that, as far as professional migration is concerned, it is not the poor who migrate from India; rather, those from better-off families, who have employment opportunities at home, migrate for better employment opportunities in the developed world. He notes that the US attracts the largest number of educated migrants from India, with around two million migrants living in the US. He attributes this to the migrants' low wages and high productivity, which increase employers' willingness to engage them. He points out that in 20I8, India received the highest amount of remittances at USD 79 billion, followed by China ( $\$ 67$ billion), Mexico (\$36 billion) and the Philippines (\$34 billion) with remittances accounting for $2.7 \%$ of India's GDP. Raising the hypothetical question of whether the professionals would have obtained better opportunities had they stayed in their own countries, Varghese does not offer a conclusive statement, but makes the point that, if well managed, migration becomes mutually beneficial to both the countries of origin and destination. In conclusion, he highlights the country's shift from articulating mobility in a deficit mode of brain drain to brain gain and the role Indian professionals have played in enhancing the country's intellectual and professional prowess and in improving India's global image.

Wapmuk examines the Nigerian diaspora's contribution to the development of higher education. He holds that the country's past engagements with its diaspora focused more on inflow of investment and remittances than on academic and skills transfer. Interestingly this observation agrees with those from many other countries. Quoting the International Organisation for Migration, he notes that Nigerians, who are also highly educated, constitute the largest population of African migrants in industrialised countries in Europe, the US and elsewhere (IOM, 20I2). Prompted by a key question that interrogates the extent to which the Nigerian diaspora has been engaged in the country's higher education sector, he raises several other relevant issues with implications for higher education. He observes that since the country returned to democratic rule in I999, it has responded positively-including committing resources-to enhance diaspora initiatives and engagements for national development in general, and development of higher education in particular. Noting the list of real and potential activities, Wapmuk also cites several challenges that constrain the tapping of the diaspora's full potential, including insecurity, inaccurate data, the lack of an enabling environment, and the government's slow response to distress calls from the diaspora.

Describing the phenomenon of African diaspora migration in waves, Oanda and Obonyo envisage three such forms driven by different global developments: Pan-Africanism, the Cold War and globalisation, and provide an extensive analysis of each. They observe that interest in seeking support from the African academic diaspora to enhance and sustain capacity in African universities has grown following the African diaspora summit organised by the AU in 20I2, which subsequently led to the creation of the Diaspora Division within the Union. They observe that, while several countries have designed diaspora policies and/or created diaspora desks in their ministries of Foreign Affairs, these initiatives fall far short of creating the right incentives for diaspora engagement, especially in higher education. As do others in this special issue, Oanda and Obonyo note that countries have focused on monetary remittances and setting up business schemes and have rarely designed incentives to attract the diaspora to engage in the higher education sector. This leaves little room to recoup 'intellectual remittances', which could oil democratic institutions and accountable political systems, especially when this relates to enabling the diaspora to participate in political processes.

\section{Conclusion}

The role and contribution of the intellectual diaspora in advancing higher education in Africa are now well established. Countries are actively seeking to tap them in a more enhanced way through duly established offices at ministries, typically foreign/home affairs, and international offices at institutional level.

It appears that the world has now been conditioned to transition from the deficit laden and emotive ridden discourse in the form of 'brain drain' that dominated the dialogue on human mobility for a long time, to a trendy, rewarding and pragmatic form in 'brain circulation'. This growing trend is robustly manifesting itself at the centre of the interchange between the intellectual diaspora and higher education in developing and emerging countries.

COVID-I9 has pushed teaching and learning from the margins to the mainstream as higher education became totally dependent on technology. 
Online teaching, learning, seminars and conferences have become an everyday reality of both regular and, of course, distance-based institutions. This has opened up an opportunity for diaspora communities to actively engage even more in the business of higher education. In a number of topical issues, most notably COVID-I9 related ones, the diaspora has visibly engaged with home based institutions in research, consultancy, joint publications, workshops and conferences. The COVID-I9 mishap has shattered more barriers-and created more opportunities-and these developments are anticipated to deepen the intellectual diaspora's engagement even more.

\section{Damtew Teferra}

April 202I

\section{teferra@ukzn.ac.za|teferra@bc.edu}

\section{References}

African Union. African Diaspora. https://au.int/en/diaspora-division\#: : text=The\%2oAfrican\%2oUnion\%2odefines\%2othe,constitutive\%20 act $\% 2$ odeclares\%2othat\%2oit

African Union Commission. (2019). The Continental Forum on Diaspora, Higher Education, Research and Innovation in Africa. https://au. int/en/newsevents/20I9IıI3/continental-forum-diaspora-higher-education-research-and-innovation-africa

Carnegie Corporation of New York. (20I9). Investing in Diaspora Exchange: Impact Evaluation of The Carnegie African Diaspora Fellowship Program https://www.carnegie.org/topics/topic-articles/african-academicdiaspora/investing-diaspora-exchange/

Dell, S. (2020). Tapping into the diaspora - The search for sustainability. University World News. 22 February 2020. https://www.university worldnews.com/post.php? story=20200220140329162

Foulds, K., and Zeleza, P. T. (20I4). The African Academic Diaspora and African Higher Education. International Higher Education 76, I6-I7.

SOFRECO. (2007). Study on the contribution of the alumni and diaspora to the Joint Africa-EU Strategy: Final report. https://africa-eu-partnership.org/sites/default/files/userfiles/study-sofreco-eu-africa_en.pdf

Teferra, D. (2003). Unleashing the Forces of the Diaspora: Capitalizing on Brain Drain in the Era of Information and Communication Technologies. https://horizon.documentation.ird.fr/exl-doc/pleins_textes /diversio-04/010047989.pdf
Teferra, D. (2004). Mobilizing Africa's Intellectual Diaspora. International Higher Education 20-22.

Teferra, D. (2005). Brain Circulation: Unparalleled Opportunities, Underlying Challenges, and Outmoded Presumptions. JSIE 9(3), 229-250. https://doi.org/Io.II77/I0283153052776I9

Teferra, D (20I8). Unleashing the Forces of the Ethiopian Intellectual Diaspora. https://ecadforum.com/2018/07/04/unleashing-the-forces -of -the -ethiopian-intellectual-diaspora/ 